\title{
Erratum: Rêgo Segundo, A.K.; et al. Capacitive Impedance Measurement: Dual-Frequency Approach. Sensors 2019, 19, 2539
}

\author{
Alan Kardek Rêgo Segundo ${ }^{1, * \mathbb{D}}$, Érica Silva Pinto ${ }^{1,2}$, Gabriel Almeida Santos ${ }^{1,2} \mathbb{D}$ \\ and Paulo Marcos de Barros Monteiro ${ }^{1}$ \\ 1 Escola de Minas, Universidade Federal de Ouro Preto (UFOP), Morro do Cruzeiro, \\ 35400-000 Ouro Preto, MG, Brazil; erica.lins15@gmail.com (É.S.P.); gabrielalmeida.el@gmail.com (G.A.S.); \\ pmemop@gmail.com (P.M.d.B.M.) \\ 2 Instituto Tecnológico Vale (ITV), Avenida Juscelino Kubitschek, 31, Bauxita, 35400-000 Ouro Preto, MG, Brazil \\ * Correspondence: alankardek@ufop.edu.br; Tel.: +55-31-98866-6595; Fax: +55-31-3559-1533
}

check for updates

Citation: Rêgo Segundo, A.K.; Silva Pinto, É.; Almeida Santos, G.; de Barros Monteiro, P.M. Erratum: Rêgo Segundo, A.K.; et al. Capacitive Impedance Measurement: Dual-Frequency Approach. Sensors 2019, 19, 2539. Sensors 2021, 21, 2149. https:/ / doi.org/10.3390/s21062149

Received: 20 February 2021

Accepted: 2 March 2021

Published: 19 March 2021

Publisher's Note: MDPI stays neutral with regard to jurisdictional claims in published maps and institutional affiliations.

Copyright: (c) 2021 by the authors. Licensee MDPI, Basel, Switzerland. This article is an open access article distributed under the terms and conditions of the Creative Commons Attribution (CC BY) license (https:// creativecommons.org/licenses/by/ $4.0 /)$.

\section{Text Correction}

There was two errors in the original article [1].

1. On page 3, instead of "The real parts of (1) and (2) are related to the losses by Joule effect.", it should read: "The real part of (3) is related to the losses by Joule effect".

A correction has been made to Section 2. Theory, 3rd Paragraph:

The impedance $(\mathbf{Z})$ of a material corresponds to the ratio between the voltage $(\mathbf{V})$ and the current (I) phasors, according to Ohm's law in complex notation, that is

$$
\mathbf{Z}=R+j \mathbf{X}
$$

where $R$ is the resistance $(\Omega)$ and $X$ the reactance $(\Omega)$. The real part of $(3)$ is related to the losses by Joule effect. The imaginary part is the ability to exchange energy.

2. On page 5, both Equations (8) and (9) should have $C_{f}^{2}$ instead of $C_{x}^{2}$ in the denominator.

A correction has been made to Section 2. Theory, Equations (8) and (9):

$$
\begin{aligned}
& A_{0}=\sqrt{\frac{G_{x}^{2}+\omega_{0}^{2} C_{x}^{2}}{G_{f}^{2}+\omega_{0}^{2} C_{f}^{2}}} \\
& A_{1}=\sqrt{\frac{G_{x}^{2}+\omega_{1}^{2} C_{x}^{2}}{G_{f}^{2}+\omega_{1}^{2} C_{f}^{2}}}
\end{aligned}
$$

The authors apologize for any inconvenience caused and state that the scientific conclusions are unaffected. The original article has been updated.

\section{Reference}

1. Rêgo Segundo, A.K.; Silva Pinto, É.; Almeida Santos, G.; de Barros Monteiro, P.M. Capacitive Impedance Measurement: Dual-frequency Approach. Sensors 2019, 19, 2539. [CrossRef] 